\title{
Hubungan Hasil Tangkapan Ikan Tuna Selama Februari- Maret 2016 dengan Konsentrasi Klorofil-a dan SPL dari Data Penginderaan Jauh Di Perairan Selatan Jawa - Bali
}

\author{
I Made Ekayana a*, I Wayan Gede Astawa Karang a , Abd. Rahman As-syakur a, \\ Irwan Jatmiko ${ }^{b}$, Dian Novianto ${ }^{b}$ \\ a Program Studi Ilmu Kelautan, Fakultas Kelautan dan Perikanan, Universitas Udayana, Kampus UNUD Bukit Jimbaran, Bali 80361, Indonesia \\ ${ }^{b}$ Loka Penelitian Perikanan Tuna, Kementerian Kelautan dan Perikanan, Jalan Mertasari Nomor 140 Sidakarya, Denpasar, Bali 80224, Indonesia \\ * Penulis koresponden. Tel.: +62-812-373-807-38 \\ Alamat e-mail: adde.kesha@gmail.com
}

Diterima (received) 17 November 2016; disetujui (accepted) 3 Februari 2017; tersedia secara online (available online) 5 Februari 2017

\begin{abstract}
Indonesia waters are fertile waters marked by the existence of Regional Fisheries Management (WPP), one of them is WPP 573 in Southern Java. One of the biggest fish catch sectors in Indonesia is tuna fisheries. Distribution of tuna in Indonesia waters affected by Sea Surface Temperature (SST) and chlorophyll-a. The aims of this study is to analyze the distribution of chlorophyll-a and SST in the water of South Java - Bali using AQUA MODIS satellite through data in-situ, to know the accuracy of SST Ground Truth and SST imagery satellite and to find the relationship between chlorophyll-a and SST with catches tuna in the water of South Java - Bali. SST data and chlorophyll-a were obtained through remote sensing technology and the catches of tuna was obtained by in-situ. The methods used were polynomial regression analysis, regression linear analysis and correlation analysis to determine the relationship of these parameters, found strong correlation between SST Ground Truth and SST imagery satellite $\mathrm{R}=0,61$. The distribution of oceanographic parameters (SST and chlorophyll-a) in the water of South Java - Bali seemed volatile and these condition also seemed less affected catches of tuna. Found low inverse correlation SST with catches of tuna amounted to $\mathrm{R}=-0.34$ and low correlation with the chlorophyll-a with catches of tuna amounted to $\mathrm{R}=0.28$.
\end{abstract}

Keywords: sea surface temperature (SST); chlorophyll-a; catch tuna

\begin{abstract}
Abstrak
Perairan Indonesia merupakan perairan yang subur dengan ditandai adanya Wilayah Pengelolaan Perikanan (WPP), salah satunya adalah WPP 573 di selatan Jawa. Salah satu sektor tangkapan ikan terbesar di Indonesia adalah perikanan tuna. Sebaran ikan tuna di perairan Indonesia dipengaruhi oleh Suhu Permukaan Laut (SPL) dan Klorofil-a. Tujuan dari penelitian ini adalah untuk menganalisa sebaran klorofil-a dan SPL di perairan selatan Jawa - Bali dari satelit Aqua MODIS, untuk memvalidasi data SPL citra satelit Aqua MODIS dan untuk mencari hubungan antara klorofil-a dan SPL dengan hasil tangkapan ikan tuna di perairan selatan Jawa - Bali. Untuk data SPL dan klorofil-a diperoleh melalui teknologi penginderaan jauh dan hasil tangkapan ikan tuna di peroleh secara in-situ. Metode yang digunakan adalah analisis regresi polinomial dan untuk mengetahui hubungan SPL lapangan dengan SPL citra satelit digunakan analisis regresi linier dan analisis korelasi untuk mengetahui hubungan parameter tersebut, dimana didapatkan korelasi yang kuat antara SPL lapangan dengan SPL citra satelit $R=0,61$. Sebaran parameter oseanografi SPL dan klorofil-a di perairan selatan Jawa - Bali terlihat fluktuatif dan kondisi ini juga terlihat sangat kecil mempengaruhi hasil tangkapan ikan tuna. Didapatkan korelasi yang rendah terbalik antara data SPL dengan hasil tangkapan tuna sebesar $\mathrm{R}=-0,34$ dan korelasi yang rendah antara data klorofil-a dengan hasil tangkapan ikan tuna sebesar $\mathrm{R}=0,28$.
\end{abstract}

Kata Kunci: suhu permukaan laut (SPL); klorofil-a; hasil tangkapan ikan tuna 


\section{Pendahuluan}

Luas wilayah teritorial Indonesia yang sebesar 7,1 juta $\mathrm{km}^{2}$ didominasi oleh wilayah laut yaitu kurang lebih 5,4 juta $\mathrm{km}^{2}$ (Santoso, 2015). Indonesia memiliki potensi perairan kususnya di bidang perikanan dengan jumlah tangkapan ikan 6,4 juta ton/tahun (IOTC, 2014). Perairan Indonesia khususnya di daerah Samudera Hindia memiliki potensi kekayaan dasar laut yang sangat besar, contohnya di bidang perikanan ikan tuna (Swastana dkk., 2016; Amandè et al., 2012). Ikan tuna merupakan anggota family secombridae. Dilihat ukurannya terdapat dua jenis tuna yang biasa dijumpai di Indonesia yaitu kelompok tuna besar dan tuna kecil (Kaplan et al., 2014).

Menurut Muqsit dkk. (2016) jenis tuna besar yang selama ini banyak di jumpai di Indonesia adalah tuna sirip kuning (Thunnus albacares), tuna mata besar (Thunnus obesus), albakora (Thunnus alalunga), dan tuna sirip biru (Thunnus maccoyii). Selain itu terdapat jenis tuna yang ukurannya relative kecil yang terdiri dari cakalang (Katsuwonus pelamis) dan tongkol (Auxis sp). Tuna merupakan ikan perenang cepat dan hidup bergerombol membentuk schooling, terutama pada waktu mencari makan (Nuraini dkk., 2014). Migrasi ikan tuna di perairan Indonesia merupakan bagian dari jalur migrasi tuna dunia karena wilayah Indonesia terletak pada lintasan perbatasan perairan antara Samudera Hindia dan Samudera Pasifik. Migrasi kelompok tuna yang melintasi wilayah perairan pantai dan teritorial terjadi karena perairan Indonesia berhubungan langsung dengan perairan kedua samudera oleh karena itu perairan Indonesia memiliki potensi perikanan yang tinggi.

Daerah tangkapan ikan (fishing ground) sangat bermanfaat bagi armada perikanan untuk menentukan letak sasaran lokasi ikan, sehingga operasi penangkapan ikan dapat direncanakan dan diperhitungkan dengan baik sehingga biaya operasional dapat dihemat melalui penghematan bahan bakar minyak dan biaya tenaga kerja. Dengan kemajuan teknologi atau riset di bidang perikanan dan kelautan upaya pembuatan informasi tersebut semakin mudah dan akurat untuk menentukan keberadaan ikan dengan mendeteksi klorofil-a di perairan. Menurut Sofarini (2012), indikator kesuburan perairan dapat diukur dari kandungan klorofil-a. Persebaran klorofil-a diperairan Samudera Hindia dipengaruhi oleh beberapa parameter contohnya SPL (Suhu Permukaan Laut), kecepatan angin, dan upwelling. Daerah perairan yang subur atau daerah yang terjadi upwelling di tandai dengan adanya aktifitas tangkapan ikan salah satu contoh daerah penangkap ikan di Indonesia adalah Wilayah Pengelolaan Perikanan (WPP).

Dari beberapa Wilayah Pengelolaan Perikanan Republik Indonesia (WPP), salah satunya adalah WPP 573 yang berlokasi di perairan selatan Jawa Bali tepatnya di Samudera Hindia pada umumnya memiliki hasil tangkapan yang brelimpah (IOTC, 2014). Kurangnya observasi kelautan dari data insitu maupun penulis di WPP 573 dikarenakan observasi dilapangan memerlukan biaya yang besar. Oleh sebab itu salah satu solusi yang paling tepat untuk mendeteksi kandungan konsentrasi klorofil-a dan suhu permukaan laut (SPL) di perairan yaitu dengan menggunakan penginderaan jauh.

Penginderaan jauh merupakan suatu teknik yang dapat diaplikasikan untuk pengamatan parameter oseanografi perairan seperti kandungan klorofil-a dan suhu permukaan laut (SPL) baik secara spasial maupun temporal. Teknik penginderaan jauh memiliki kemampuan yang tinggi dalam menganalisis area yang luas dan sulit ditempuh dengan cara konvensional dalam waktu yang singkat (Syah, 2010). Salah satu satelit penginderaan jauh yang dilengkapi dengan sensor yang dapat mendeteksi kandungan klorofil-a pada perairan adalah satelit Aqua Moderate Resolution Imaging Spectroradiometer (MODIS). Satelit Aqua MODIS merupakan satelit ilmu pengetahuan tentang bumi dari Nation Aeronautics and Space Administration (NASA), yang mempunyai kelebihan dapat mengukur kandungan konsentrasi klorofil-a dan SPL diperairan (Kasim, 2010).

Penelitian mengenai hubungan kondisi perairan yang diamati melalui satelit penginderaan jauh dan hasil tangkapan ikan sudah pernah dilakukan. Pada WPP 711 dilakukan oleh Prasetyo dkk. (2014), WPP 712 oleh Usman dkk. (2014) dan WPP 572 oleh Hariyanto dkk. (2008). Sedangkan selatan Jawa - Bali (WPP 573) sudah banyak dilakukan penelitian, tetapi yang turun langsung ke lapangan untuk melakukan pengambilan data oseanografi sangat jarang, oleh karena itu penelitian ini penting dilakukan. Penelitian ini bertujuan dan untuk mengetahui sebaran SPL dan klorofil-a di perairan selatan 
Jawa-Bali dan Untuk mengatahui tingkat keakuratan data SPL citra satelit dengan SPL lapangan serta Untuk mengetahui hubungan konsentrasi klorofil-a dan SPL terhadap tangkapan ikan tuna dengan menggunakan penginderaan jauh.

\section{Metode Penelitian}

\subsection{Waktu dan Lokasi Penelitian}

Pengambilan data dilapangan dilaksanakan pada tanggal 21 Februari - 25 Maret tahun 2016 di perairan selatan Jawa - Bali. Dimana pengambilan data pertama dilakukan pada titik koordinat pada titik koordinat S 09 $15^{\prime} 438^{\prime \prime}$ - E 108 $28^{\prime} 386^{\prime \prime}$ dan pengambilan data berakhir pada titik koordinat $S$ 10³2'031" - E 10849'396" dapat dilihat pada Gambar 1.

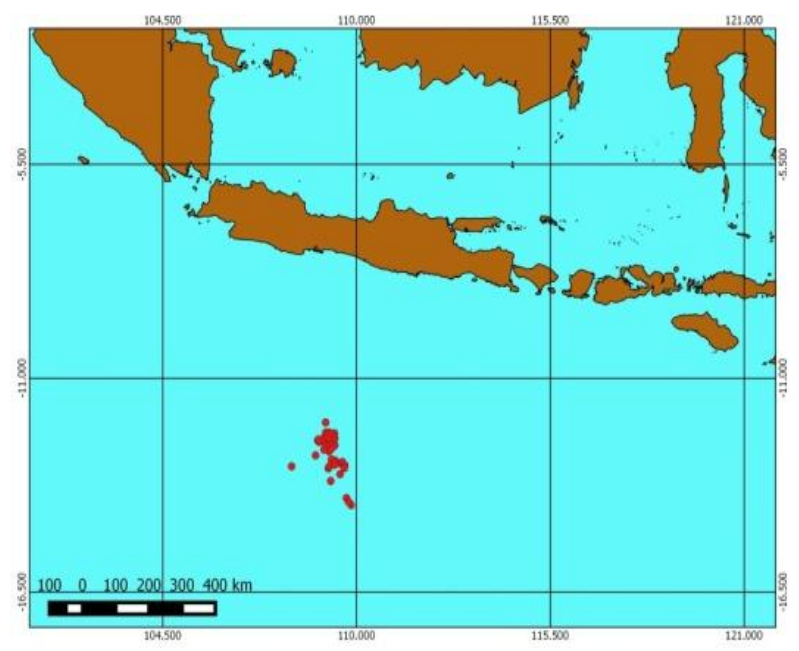

Gambar 1. Peta Lokasi Penelitian. Titik merah mengindikasikan koordinat lokasi tangkapan ikan tuna di perairan selatan Jawa - Bali.

\subsection{Alat dan Bahan}

Alat yang digunakan dalam penelitian ini adalah Global Positioning System (GPS) untuk penentuan posisi, Digital camera untuk dokumentasi, Kapal untuk transportasi dan tempat pengukuran parameter oseanografi dan mini Logger (depth dan temperature).

Bahan yang di gunakan dalam penelitian ini adalah data SPL yang didapat melalui satelit Aqua MODIS yaitu data citra satelit SPL harian yang memiliki resolusi $1 \mathrm{Km}$ dan Data Klorofil-a yang di dapat melalui satelit Aqua MODIS yaitu data citra klorofil-a harian yang memiliki resolusi $1 \mathrm{Km}$. (http://www.oceancolor.gsfc.nasa.gov)

\subsection{Pengambilan Data SPL Lapangan}

Data primer diperoleh dengan mengikuti langsung operasi kapal penangkapan yang memiliki tonase kotor antara 14-149 GT dengan spesifikasi terdiri dari tali utama tali cabang (branch line), tali pelampung, mata pancing (hook), pelampung (float) dan pelampung radio (Jatmiko dkk., 2015). Dimana pengambilan SPL lapangan menggunakan Mini Logger. Mini logger merupakan alat pengukur suhu dan kedalaman di suatu perairan, alat ini bekerja dengan merekam suhu dan kedalaman selama per detik. Pengambilan SPL lapangan dilakukan dengan memasang mini logger pada tali brancline pada saat setting dengan mecatat waktu dan koordinat pada saat penurunan mini logger. Dimana hasil dari pengukuran suhu lapangan alat ini akan divalidasi dengan suhu citra satelit. Dalam pengukuran suhu dilapangan alat ukur tersebut mulai merekam saat pertama alat tersebut menyentuh air. Dimana dalam penelitian ini hanya digunakan rata - rata suhu lapangan selama satu menit pada kedalam alat yang berkisar antara satu meter sampai dua meter. Adapun data primer yang diambil dalam penelitian ini adalah sebagai berikut :

a. Koordinat melalui data in-situ

b. SPL yang di dapat melalui satelit Aqua MODIS (Ocean colour), yaitu data harian level 2 dengan resolusi $1 \mathrm{Km}$.

c. Klorofil-a yang di dapat melalui satelit Aqua MODIS (Ocean colour), yaitu data harian level 2 dengan resolusi $1 \mathrm{Km}$.

d. Hasil tangkapan ikan melalui data in-situ

e. SPL yang didapatkan melalui data in-situ

\subsection{Analisis Data}

Analisis hubungan SPL dan konsentrasi klorofil-a dengan hasil tangkapan ikan tuna di analisis menggunakan analisis regresi polinomial dengan metode diskriminan dan untuk mengetahui akurasi hubungan SPL citra satelit dengan SPL lapangan digunakan analisi regresi linier. Untuk analisis korelasi menggunakan persamaan 3, dimana hubungan linier sempurna terjadi antara $x$ dan y bila nilai $\mathrm{r}$ mendekati nol maka hubungan nilai $x$ dan $y$ sangat lemah. Hipotesis yang digunakaan dalam penelitian ini bahwa tingginya sebaran SPL dan konsentrasi klorofil-a mengindikasikasikan keberadaan dari ikan tuna di perairan. Analisis regresi polinomial digunakan untuk mengetahui pengaruh dari hasil tangkapan 
dengan parameter oseanografi SPL dan klorofil-a di perairan dapat dilihat pada persamaan 1 sedangkan regresi linier untuk validasi data SPL lapangan dengan SPL citra satelit dijelaskan dalam persamaan 2 (Bender et al., 2014).

$Y=a_{0}+a_{1} x+a_{2} x^{2}$

dimana $\mathrm{Y}$ adalah hasil tangkapan ikan tuna, $a$ adalah konsatanta dan $x$ adalah Parameter oseanografi yaitu SPL dan klorofil-a.

$Y=a+b x$

dimana Y adalah SPL lapangan dan $x$ aladah SPL citra satelit.

$r=\frac{\sum \mathrm{xy}-\frac{\left(\sum \mathrm{x}\right)\left(\sum \mathrm{y}\right)}{n}}{\sqrt{\left(\sum x^{2}-\frac{\left(\sum \mathrm{x}\right)^{2}}{n}\right)}\left(\sum y^{2}-\frac{\sum \mathrm{y}^{2}}{n}\right)}$

dimana $\mathrm{r}$ adalah koefisien korelasi, $x$ adalah hasil tangkapan ikan tuna dan $y$ adalah parameter oseanografi SPL dan klorofil-a.

\section{Hasil}

\subsection{Sebaran SPL Citra Satelit dan Klorofil-a di Selatan Jawa Bali}

Data oceanografi SPL dan klorofil-a diambil dari citra satelit data MODIS level 2 yang memiliki resolusi $1 \mathrm{Km}$ diunduh melalui website dengan alamat http://www.oceancolor.gsfc.nasa.gov yang datanya dimulai tanggal 21 Februari sampai 17 Maret 2016. Analisis citra satelit SPL dan klorofil-a tersebut dapat dilihat pada Tabel 1 yang menunjukan adanya fluktuasi SPL dan variasi klorofil-a.

\subsection{Sebaran SPL}

Hasil pengolahan citra satelit pada bulan Februari 2016 di perairan Selatan Jawa - Bali, didapatkan rata - rata SPL yaitu $27,72^{\circ} \mathrm{C}$. Gambar 2 menunjukan bahwa pada bulan tersebut didapatkan suhu tertinggi dengan nilai $32,64^{\circ} \mathrm{C}$ yang berada pada wilayah lokasi penangkapan ikan tuna dan dekat perairan Australia, sedangkan suhu terendah yaitu didapatkan dengan nilai $20^{\circ} \mathrm{C}$. Berdasarkan hasil ini suhu pada daerah selatan Jawa - Bali memiliki suhu yang relative tinggi dan suhu semakin menurun pada daerah yang mengarah ke pusat perairan Samudera Hindia.

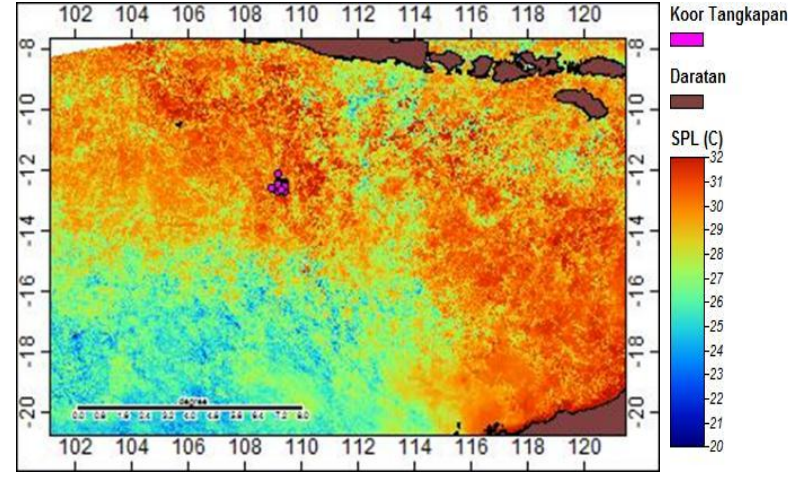

Gambar 2. Sebaran SPL bulan Februari di perairan selatan Jawa-Bali

Hasil pengolahan citra satelit pada bulan Maret 2016 di perairan selatan Jawa - Bali didapatkan rata - rata sebaran SPL $27,81^{\circ} \mathrm{C}$. Gambar 3 menunjukan bahwa pada bulan tersebut didapatkan suhu tertinggi dengan nilai $32,21^{\circ} \mathrm{C}$ yang berada pada lokasi penangkapan, sedangkan suhu terendah didapatkan dengan nilai yaitu $20^{\circ} \mathrm{C}$. Berdasarkan hasil ini suhu pada daerah selatan Jawa - Bali memiliki suhu yang cenderung tinggi dan suhunya semakin menurun pada daerah yang mengarah ke perairan Samudera Hindia.

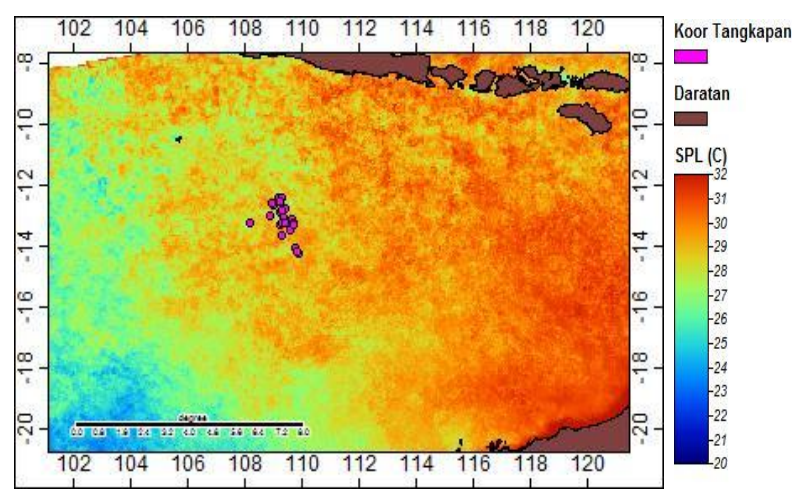

Gambar 3. Sebaran SPL bulan Maret di perairan selatan Jawa - Bali

\subsection{Sebaran klorofil-a}

Hasil pengolahan citra satelit pada bulan Februari 2016 di perairan selatan Jawa - Bali didapatkan rata - rata sebaran konsentrasi klorofil-a dengan nilai $0,12 \mathrm{mg} / \mathrm{m}^{3}$. Gambar 4 menunjukan bahwa pada tanggal tersebut didapatkan sebaran konsentrasi klorofil-a tertinggi dengan nilai 2,8 $\mathrm{mg} / \mathrm{m}^{3}$ yang berada pada perairan dekat dengan daratan, sedangkan sebaran konsentrasi klorofil-a terendah didapatkan dengan nilai yaitu 0,01 $\mathrm{mg} / \mathrm{m}^{3}$ yang berada pada lokasi penangkapan yang jauh dari daratan. Berdasarkan hasil ini 
sebaran konsentrasi klorofil-a pada bulan Februari perairan selatan Jawa - Bali memiliki sebaran konsentrasi klorofil-a yang tinggi dekat dengan daratan dan sebaliknya sebaran konsentrasi klorofil-a semakin menurun pada daerah yang jauh dari daratan.



Gambar 4. Sebaran klorofil-a bulan Februari di perairan selatan Jawa-Bali

Hasil pengolahan citra satelit pada bulan Maret 2016 di perairan selatan Jawa - Bali didapatkan rata - rata sebaran konsentrasi klorofil-a dengan nilai $0,13 \mathrm{mg} / \mathrm{m}^{3}$. Gambar 5 menunjukan bahwa pada bulan tersebut didapatkan sebaran konsentrasi klorofil-a tertinggi dengan nilai 2,2 $\mathrm{mg} / \mathrm{m}^{3}$ yang berada pada dekat dengan daratan, sedangkan sebaran konsentrasi klorofil-a terendah didapatkan jauh dengan daratan yaitu dengan nilai $0,01 \mathrm{mg} / \mathrm{m}^{3}$. Berdasarkan hasil ini sebaran konsentrasi klorofil-a pada bulan Maret di perairan selatan Jawa - Bali memiliki sebaran konsentrasi klorofil-a yang tinggi dekat dengan daratan dan sebaliknya sebaran konsentrasi klorofil-a semakin menurun pada daerah yang jauh dari daratan.

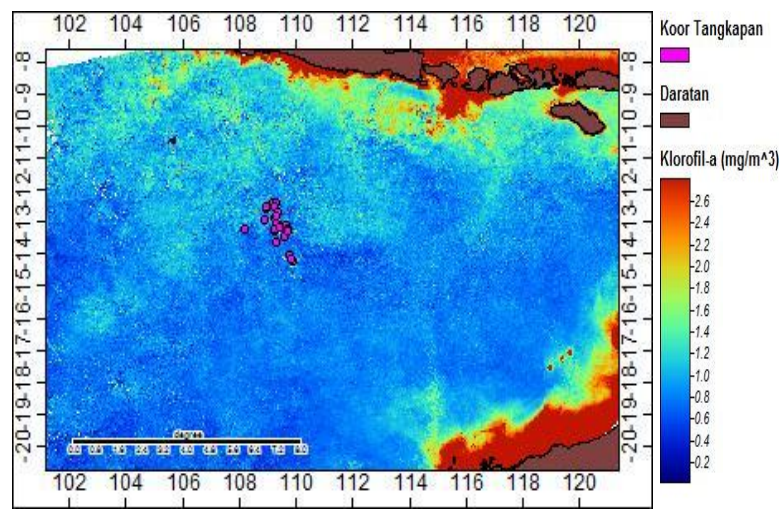

Gambar 5. Sebaran klorofil-a bulan Maret di perairan selatan Jawa-Bali
Tabel 1

Data Oseanografi Klorofil-a dan SPL Citra Satelit Serta Hasil Tangkapan Ikan Tuna

\begin{tabular}{|c|c|c|c|c|}
\hline \multirow[b]{2}{*}{ No } & \multirow[b]{2}{*}{ Tanggal } & \multicolumn{2}{|c|}{ Parameter Oseanografi } & \multirow{2}{*}{$\begin{array}{c}\text { Hasil } \\
\text { Tngkapan } \\
\text { (ekor) }\end{array}$} \\
\hline & & $\begin{array}{c}\begin{array}{c}\text { Klorofil-a } \\
\left(\mathrm{mg} / \mathrm{m}^{3}\right)\end{array} \\
\end{array}$ & $\operatorname{SPL}\left({ }^{\circ} \mathrm{C}\right)$ & \\
\hline 1 & $23 / 2 / 2016$ & 0.079 & 29.2 & 6 \\
\hline 2 & $24 / 2 / 2016$ & 0.050 & 30.5 & 8 \\
\hline 3 & & 0.067 & 31.6 & 4 \\
\hline 4 & & 0.079 & 31.0 & 2 \\
\hline 5 & & 0.050 & 31.4 & 1 \\
\hline 6 & $25 / 2 / 2016$ & 0.066 & 31.0 & 4 \\
\hline 7 & & 0.031 & 31.1 & 5 \\
\hline 8 & & 0.048 & 31.6 & 2 \\
\hline 9 & & 0.071 & 32.9 & 4 \\
\hline 10 & $26 / 2 / 2016$ & 0.078 & 32.5 & 4 \\
\hline 11 & & 0.059 & 30.5 & 1 \\
\hline 12 & & 0.073 & 32.6 & 2 \\
\hline 13 & & 0.079 & 32.2 & 1 \\
\hline 14 & $27 / 2 / 2016$ & 0.081 & 20.6 & 5 \\
\hline 15 & $1 / 3 / 2016$ & 0.077 & 25.8 & 4 \\
\hline 16 & & 0.082 & 25.4 & 5 \\
\hline 17 & & 0.097 & 27.6 & 12 \\
\hline 18 & & 0.072 & 25.7 & 7 \\
\hline 19 & & 0.077 & 28.0 & 8 \\
\hline 20 & & 0.066 & 30.0 & 3 \\
\hline 21 & $3 / 3 / 2016$ & 0.058 & 31.7 & 1 \\
\hline 22 & & 0.084 & 28.6 & 2 \\
\hline 23 & $7 / 3 / 2016$ & 0.066 & 31.0 & 3 \\
\hline 24 & & 0.070 & 31.2 & 2 \\
\hline 25 & & 0.086 & 31.2 & 2 \\
\hline 26 & & 0.067 & 31.2 & 1 \\
\hline 27 & & 0.068 & 30.8 & 5 \\
\hline 28 & $10 / 3 / 2016$ & 0.065 & 29.4 & 2 \\
\hline 29 & $11 / 3 / 2016$ & 0.041 & 30.2 & 1 \\
\hline 30 & & 0.047 & 30.2 & 3 \\
\hline 31 & & 0.041 & 30.2 & 1 \\
\hline 32 & $12 / 3 / 2016$ & 0.059 & 28.6 & 1 \\
\hline 33 & & 0.067 & 29.4 & 2 \\
\hline 34 & & 0.067 & 29.7 & 2 \\
\hline 35 & $14 / 3 / 2016$ & 0.060 & 28.9 & 1 \\
\hline 36 & & 0.087 & 27.9 & 1 \\
\hline 37 & & 0.076 & 28.3 & 2 \\
\hline 38 & $16 / 3 / 2016$ & 0.057 & 29.9 & 5 \\
\hline 39 & $17 / 3 / 2016$ & 0.044 & 29.5 & 2 \\
\hline
\end{tabular}


3.4 Analisis Perbandingan SPL Lapangan Dengan SPL Citra Satelit

Data lapangan SPL atau Ground truth diambil pada tanggal 23 Februari sampai 25 Maret 2016 di perairan selatan Jawa - Bali dengan menggunakan mini loger. Data SPL diambil menggunakan mini loger pada lokasi setting maupun hauling. Dari 29 setting dan hauling, hanya 20 data yang bias digunakan akibat ketiadaan data SPL satelit karena tertutup oleh awan. Hasil dari pengukuran SPL lapangan ditunjukan pada Tabel 2 yang menujukkan bahwa rata-rata SPL di perairan selatan Jawa - Bali adalah sebesar $29,9^{\circ} \mathrm{C}$. Suhu tertinggi dari pengambilan sampel lapangan adalah $32,4^{\circ} \mathrm{C}$ dan suhu terendah adalah $27,3^{\circ} \mathrm{C}$.

Tabel 2

Pengelompokan SPL Lapangan dengan SPL Citra Satelit

\begin{tabular}{ccc}
\hline No & \multicolumn{2}{c}{ Parameter } \\
\cline { 2 - 3 } & $\begin{array}{c}\text { Suhu } \\
\text { Lapangan } \\
\left({ }^{\circ} \mathbf{C}\right)\end{array}$ & $\begin{array}{c}\text { Suhu } \\
\text { Citra } \\
\text { Satelit } \\
\left({ }^{\circ} \mathbf{C}\right)\end{array}$ \\
\hline 1 & 32.4 & 30.0 \\
2 & 28.8 & 30.2 \\
3 & 32.9 & 31.4 \\
4 & 28.6 & 29.2 \\
5 & 30.7 & 31.6 \\
6 & 29.7 & 30.7 \\
7 & 31.2 & 32.2 \\
8 & 27.3 & 29.1 \\
9 & 31.3 & 27.8 \\
10 & 28.9 & 29.5 \\
11 & 32.4 & 31.7 \\
12 & 31.0 & 31.0 \\
13 & 29.9 & 29.4 \\
14 & 29.0 & 29.2 \\
15 & 31.5 & 29.6 \\
16 & 27.6 & 29.4 \\
17 & 28.1 & 30.0 \\
18 & 29.6 & 29.7 \\
19 & 29.1 & 29.2 \\
20 & 28.4 & 27.1 \\
\hline
\end{tabular}

Hasil perbandingan seperti pada Gambar 5, dapat juga mengindikasikan tingkat validitas data. Gambar 5 menunjukan adanya pola yang mirip dimana saat SPL lapangan tinggi juga diikuti oleh SPL citra yang tinggi begitu sebaliknya. Akan tetapi ada beberapa data yang polanya tidak mirip seperti pada tanggal 25/02/2016, 26/03/2016, 02/03/2016, 03/03/2016, 11/03/2016 dan 12/03/2016 dapat dilihat pada Gambar 5.

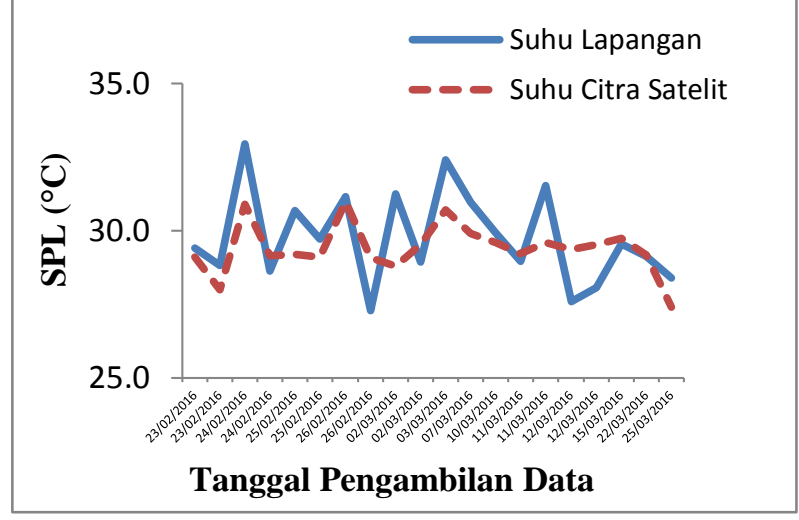

Gambar 5. Grafik Perbedaan SPL Lapangan dengan SPL Citra Satelit

\subsection{Validasi SPL Lapangan Dengan SPL Citra Satelit}

Validasi data ini dilakukan dengan mengkorelasikan data hasil SPL lapangan dengan SPL hasil pengolahan citra satelit. Pada validasi data ini dihasilkan nilai koefisien determinasi $\left(R^{2}\right)$ sebesar 0.38 dengan persamaan regresi $y=0.3362 x$ + 19.396 artinya $38 \%$ menjelaskan model persamaan regresi yang diperoleh. Nilai korelasi yang diperoleh sebesar $R=0.61$ yang divisualisasikan pada Gambar 6. Berdasarkan nilai $\mathrm{R}$ dan tabel $\mathrm{R}$, dapat disimpulkan bahwa tingkat korelasi sebesar 0.61 memiliki tingkat hubungan yang sangat signifikan (tingkat kesalahan 1\%).

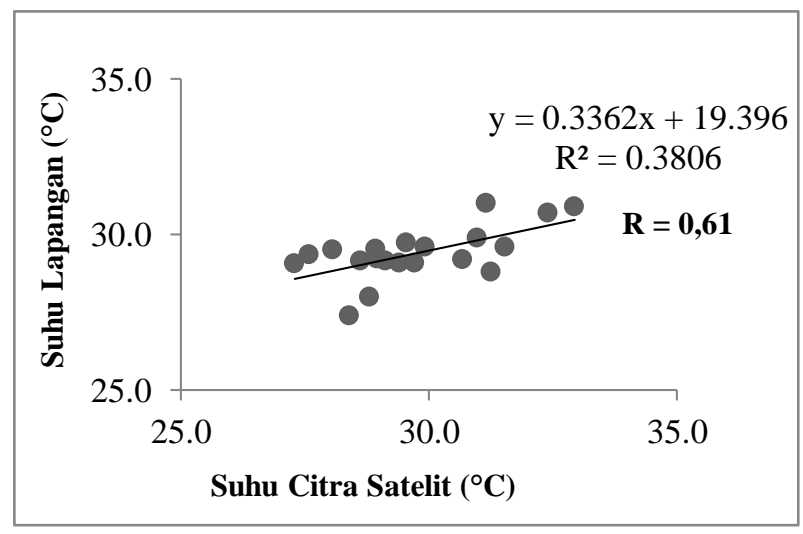

Gambar 6. Diagram Pencar Perbandingan SPL Lapangan dengan SPL Citra Satelit

\subsection{Hasil Tangkapan}

Cruise penangkapan kapal longline tuna sebanyak 29 setting dapat dilihat pada Gambar 7. Cruise dimulai dari tanggal 21 Februari pada titik koordinat S $09^{\circ} 15^{\prime} 438^{\prime \prime}$ - E $108^{\circ} 28^{\prime} 386^{\prime \prime}$ berakhir sampai tanggal 25 Maret 2016 pada titik koordinat S 10³2'031" - E 108 499'396". Pada setiap setting 
menggunakan 5 bouy untuk menandakan koordinat setting.

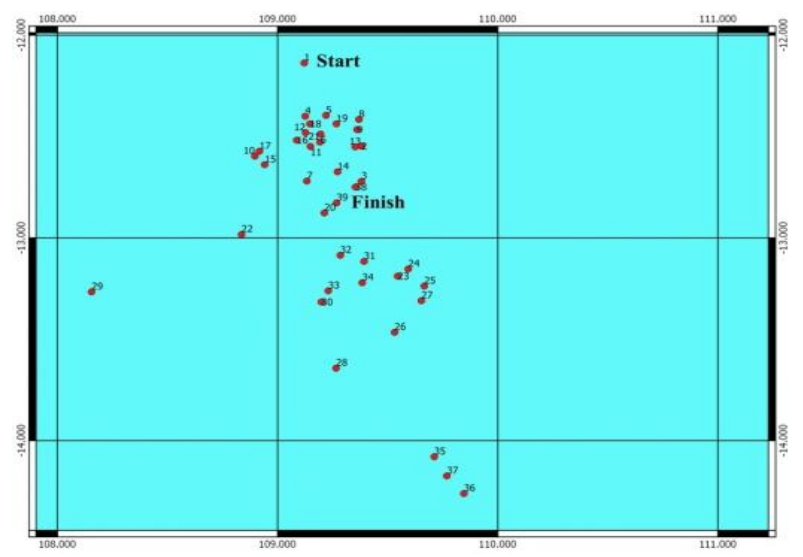

Gambar 7. Cruise Tangkapan Ikan Tuna Di Perairan selatan Jawa - Bali

Dari 29 setting hanya terdapat 14 setting yang mendapatkan ikan tuna dan sedangkan 15 setting lainnya hanya mendapatkan hasil tangkapan sampingan. Tanggal setting dan hasil tangkapan dapat dilihat pada Tabel 1 . Tabel 1 terlihat bahwa hasil tangkapan tertinggi sebanyak 39 ekor tuna pada setting ke 9 tanggal 1 Maret 2016. Sedangkan tangkapan terendah sebanyak 2 ekor tuna pada setting ke 17 tanggal 10 Maret dan setting ke 22 tanggal 17 Maret 2016. Jumlah total hasil tangkapan ikan tuna KM. Anna Rizky 12 selama bulan Februari - Maret 2016 mencapai 376 ekor ikan tuna. Hasil terbanyak didominasi oleh tuna Albakor sebanyak 264 ekor ikan dan Tuna Mata Besar 91 ekor. Sementara itu jenis tangkapan yang terendah hasilnya adalah Tuna Sirip Kuning 5 ekor, Tuna Sirip Biru Selatan 4 ekor, dan diikuti oleh ikan Cakalang 12 ekor. Komposisi tangkapan ikan tuna dapat dilihat pada Tabel 3.

\subsection{Hubungan Hasil Tangkapan Dengan SPL}

Untuk melihat keterkaitan antara hasil tangkapan ikan tuna dengan SPL di perairan Selatan Jawa Bali, digunakannya data in-situ hasil tangkapan tuna dengan SPL citra satelit pada bulan Februari Maret 2016. Pada analisis ini dilakukan korelasi antara SPL dengan hasil tangkapan ikan tuna dihasilkan nilai korelasi nilai koefisien determinasi $\left(R^{2}\right)=0,13$ dengan persamaan regresi $y=0.0839 x^{2}-$ $5.3626 x+88.257$ artinya $13 \%$ menjelaskan model persamaan regresi yang diperoleh. Nilai korelasi yang diperoleh sebesar $R=-0,34$ menunjukan hubungan terbalik yang rendah. Gambar 8 menunjukan grafik hubungan antara SPL dengan hasil tangkapan.

Tabel 3

Komposisi Hasil Tangkapan Ikan Tuna

\begin{tabular}{|c|c|c|c|}
\hline No & Nama Spesies & $\begin{array}{c}\text { Kode } \\
\text { Spesies }\end{array}$ & $\begin{array}{c}\text { Jumlah } \\
\text { (ekor) }\end{array}$ \\
\hline 1 & Albakora & ALB & 264 \\
\hline 2 & Tuna Mata Besar & BET & 91 \\
\hline 3 & $\begin{array}{l}\text { Tuna Sirip } \\
\text { Kuning }\end{array}$ & YFT & 5 \\
\hline 4 & $\begin{array}{l}\text { Tuna Sirip Biru } \\
\text { Selatan }\end{array}$ & SBT & 4 \\
\hline 5 & Cakalang & SKJ & 12 \\
\hline
\end{tabular}



Gambar 8. Grafik Hubungan SPL Dengan Hasil Tangakapan Ikan Tuna Di Perairan Selatan Jawa - Bali

\subsection{Hubungan Hasil Tangkapan Dengan Klorofil-a}

Untuk mengetahui hubungan antara klorofil-a dengna hasil tangkapan, pada analisis ini dilakukan korelasi antara klorofil-a dengan hasil tangkapan untuk mengetahui hubungannya, dihasilkan nilai koefisien determinasi $\left(\mathrm{R}^{2}\right)=0,19$ dengan persamaan regresi $y=3108.6 x^{2}-348.82 x+$ 12.013 artinya dari persamaan tersebut 19\% menjelaskan model persamaan regresi yang diperoleh. Nilai korelasi yang diperoleh sebesar $\mathrm{R}$ $=0,28$ dapat dilihat pada Gambar 9 .

\section{Pembahasan}

Seberan SPL di perairan sangat tergantung dari jumlah bahang yang diterima dari energi cahaya matahari, dimana daerah - daerah yang paling banyak menerima bahang energi cahaya matahari adalah daerah - daerah yang dekat dengan lintang $0^{\circ}$ dan yang nantinya berpengaruh terhadap kehidupan klorofil-a di perairan sehingga hal 
inilah yang menyebabkan SPL di laut merupakan faktor penentu tingkat kesuburan di perairan. Sebaran SPL bulan pada Februari - Maret 2016 di Selatan Jawa - Bali Gambar 2 dan 3, menunjukan adanya fluktuasi SPL secara spasial dan temporal selama bulan Februari - Maret 2016 dimana pada bulan Februari didapatkan rata - rata SPL dengan nilai $27,72^{\circ} \mathrm{C}$ dan pada bulan Maret didapatkan rata - rata dengan nilai $27,81^{\circ}$. SPL mulai menurun pada bulan Maret dimana semula pada bulan Februari suhu yang hangat di perairan selatan Jawa dipengaruhi musim hujan sehingga terbukti suhunya yang hangat, sedangkan pada bulan Maret terbukti suhunya semakin turun di sebabkan oleh perubahan musim. Sebaran SPL dipengaruhi oleh pergerakan matahari dan angin musoon, dimana hal ini sesuai dengan pernyataan Najid dkk. (2012) bahwa variasi musiman terjadi karena adanya sistem angin musoon AsiaAustralia, dimana musim barat dari bulan Desember - Februari suhunya lebih hangat dibandingkan dengan musim timur. Menurut Habibie et al. (2014), menyatakan bahwa SPL di perairan selatan Jawa - Bali (Samudera Hindia) mendapatkan asupan air hangat dari Samudera Pasifik bagian barat (warm pool) melalui arus lintas Indonesia yang bergerak dari Samudera Pasifik menuju Samudera Hindia. Sedangkan SPL terendah dengan nilai $20^{\circ} \mathrm{C}$ ditemukan di lepas pantai mengarah ke pusat perairan Samudera Hindia dikarenakan semakin jauh dari garis katulistiwa maka SPL di perairan akan semakin rendah akibat dari menurunnya intensitas cahaya matahari yang diterima di daerah tersebut.

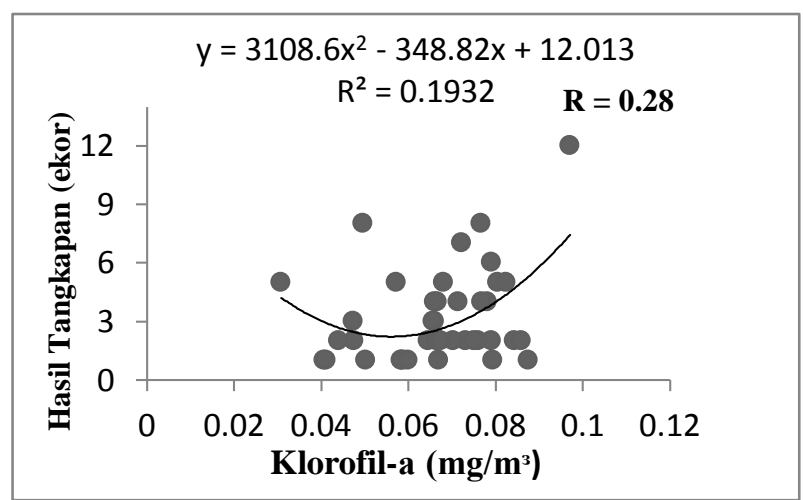

Gambar 9. Grafik Hubungan Klorofil-a Dengan Hasil Tangkapan Ikan Tuna Di Perairan Selatan Jawa - Bali

Sebaran klorofil-a di perairan sangat bervariasi tergantung terhadap intensitas cahaya matahari, dimana intensitas cahaya yang lebih tinggi mengakibatkan tingkat fotosintesis meningkat (Abigail et al., 2015). Konsentrasi klorofil-a di perairan tinggi sehingga dapat diasumsikan produktifiktas potensi tangkapan menjadi meningkat. Sebaran konsentrasi klorofil-a bulan Februari - Maret 2016 di perairan selatan Jawa Bali seperti ditunjukan oleh Gambar 4 dan 5, memperlihatkan bahwa nilai konsentrasi klorofil-a cenderung tinggi di pesisir pantai selatan Pulau Jawa - Bali.

Konsentrasi klorofil-a di perairan pantai dan pesisir relatif tinggi dibandingkan daerah laut lepas. Menurut Putra dkk. (2012) tingginya klofofil-a di pesisir pantai di sebabkan oleh curah hujan yang tinggi di daratan. Tingginya kandungan klorofil-a di pesisir pantai dikarena adanya pasokan suplai nutrien melalui run-off sungai dari daratan (Hidayah dkk., 2016). Namun pada daerah-daerah tertentu di perairan lepas pantai yang tidak menerima run-off sungai juga dijumpai konsentrasi klorofil-a dalam jumlah yang cukup tinggi. Keadaan ini diduga karena pengaruh angin musoon yang menyebabkan pola sirkulasi massa air yang berbeda dan bervariasi antara musim dimana pengaruh angin musoon ini juga diduga mengakibatkan terjadinya penaikan massa air (upwelling) di laut. Disamping itu pengaruh massa air lautan Pasifik yang melintasi perairan Indonesia menuju Samudra Hindia melalui sistem arus lintas Indonesia juga mempengaruhi terjadinya fluktuasi sebaran konsentrasi klorofil-a, dimana ketika massa air melewati perairan Indonesia, maka massa air Arlindo akan bercampur dengan massa air lainnya sehingga terjadi percampuran massa air dari dua Samudera yang berbeda (Habibie et al., 2014).

Validasi SPL lapangan dengan SPL citra satelit di perairan selatan Jawa - Bali terlihat fluktuatif. Analisi validasi menggunakan regresi linier untuk melihat perbandingan error dari kedua suhu tersebut. Gambar 6, menunjukan bahwa nilai korelasi $\mathrm{R}=0,61$ di katagorikan hubungan positif yang kuat antara SPL lapangan dengan SPL citra satelit.

Analisis SPL dan klorofil-a terhadap hasil tangkapan ikan tuna menggunakan metode regresi polinomial untuk melihat besarnya pengaruh dari SPL dan klorofil-a terhadap hasil tangkapan ikan tuna. Hasil analisis regresi polinomial menunjukan hubungan terbalik antara SPL dan hasil tangkapan ikan tuna sangat kecil Gambar 8, dengan korelasi $\mathrm{R}=-0,34$. Hasil ini bisa disebabkan karena data 
hasil tangkapan ikan yang diperoleh hanya selama dua bulan sehingga tingkat akurasi dari analisis korelasi tidak maksimal. Dalam korelasi SPL dengan hasil penangkapan ikan tuna Gambar 8, berdasarkan grafik menunjukan bahwa hubungan terbalik, dimana semakin tinggi SPL maka hasil tangkapan semakin menurun. Gambar 8 menunjukan bahwa penurunan hasil tangkapan secara drastis terjadi pada suhu yang berkisar sekitar $30^{\circ} \mathrm{C}$. Hal ini sesuai dengan penelitian Setiawati et al. (2014) bahwa hasil tangkapan tidak selalu berpengaruh terhadap sebaran SPL melainkan juga di pengaruhi oleh klorofil-a dan kedalaman. Kondisi ini membuktikan bahwa ikan tuna masih dapat mentolerir SPL dingin $20^{\circ} \mathrm{C}$ dan suhu panas sampai $31^{\circ} \mathrm{C}$. Namun demikian hasil tangkapan ikan tuna terbanyak ditemukan pada kisaran suhu $25^{\circ} \mathrm{C}-29^{\circ} \mathrm{C}$ (Limbong, 2008).

Penyebaran ikan tuna di suatu wilayah perairan tidak hanya dipengaruhi oleh satu faktor oseanografi tertentu. Kemungkinan penyebaran ikan tuna di suatu tempat secara dominan dipengaruhi oleh SPL tetapi di daerah lain penyebarannya dipengaruhi oleh arus (Limbong, 2008). Disamping itu, pengaruh SPL terhadap penyebaran ikan tuna untuk perairan tropis adalah kecil karena suhu relatif sama (konstan) sepanjang tahun. Ikan banyak tertangkap pada suhu yang rendah, diduga karena pada suhu yang tinggi ikan akan bermigrasi ke lokasi atau perairan yang lebih dalam di luar jangkauan alat tangkap yang dioperasikan nelayan. Dengan demikian peluang ikan yang tertangkap lebih kecil dan mengakibatkan hasil tangkapan menurun (Adnan, 2010).

Hubungan klorofil-a dengan hasil tangkapan ikan tuna dapat dilihat pada Gambar 9, dengan nilai korelasi $\mathrm{R}=0,28$. Hasil ini bisa disebabkan karena data hasil tangkapan ikan yang diperoleh hanya selama dua bulan sehingga tingkat akurasi dari analisis korelasi tidak maksimal. Dalam korelasi antara klorofil-a dengan hasil tangkapan Gambar 9, berdasarkan grafik menunjukan bahwa terdapat pola parabola terbuka antara klorofil-a dengan hasil tangkapan. Hasil penangkapan menurun pada konsentrasi klorofil-a $0,05 \mathrm{mg} / \mathrm{m}^{3}$, selanjutnya konsentrasi klorofil-a di atas 0,05 terjadi peningkapan hasil tangkapan secara drastis. Hasil tangkapan tertinggi diperoleh pada kadar konsentrasi klorofil-a sebesar 0,09. Dalam penelitian ini sebaran klorofil-a tinggi berada di pesisir Selatan Jawa - Bali dengan nilai konsentrasi sebesar $1,2 \mathrm{mg} / \mathrm{m}^{3}$, sedangkan daerah penelitian tangkapan tuna memiliki nilai konsentrasi klorofila rendah dikarena lokasi penelitian mengarah ke pusat perairan Samudera Hindia. Dilihat dari nilai konsentrasi klorofil-a rendah ini menyebabkan hubungan hasil tangkapan tuna dengan nilai konsentrasi klorofil-a sangat rendah dengan nilai korelasi $\mathrm{R}=0,28$. Hasil ini sejalan dengan penelitian yang dilakukan oleh Umar dkk. (2015), menyatakan bahwa klorofil-a tidak berpengaruh langsung terhadap hasil tangkapan ikan tuna, karena ikan tuna bukan konsumen pertama dalam rantai makanan. Dalam rantai makanan fitoplankton akan di makan oleh hewan herbivora yang kemudian dimangsa oleh karnivora dan selanjutnya pada tropik level yang lebih tinggi. Dengan demikian fitoplankton sebagai produsen primer, merupakan fundamen dalam rantai makanan yang mendukung kehidupan biota laut lainnya (Sofarini, 2012).

\section{Kesimpulan}

Berdasarkan hasil dari pembahasan diatas dapat ditarik kesimpulan bahwa sebaran parameter oseanografi SPL di perairan Selatan Jawa - Bali terlihat fluktuatif dengan rata - rata pada bulan Februari dengan nilai $27,72^{\circ} \mathrm{C}$ dan pada buan Maret didapatkan rata - rata dengan nilai $27,81^{\circ} \mathrm{C}$. Sedangkan sebaran klorofil-a di perairan Selatan Jawa - Bali didapatkan rata - rata pada bulan Februari dengan nilai $0,12 \mathrm{mg} / \mathrm{m}^{3}$ dan pada bulan Maret didapatkan rata - rata dengan nilai 0,13 $\mathrm{mg} / \mathrm{m}^{3}$.

Berdasarkan analisis korelasi untuk melihat akurasi dari SPL citra satelit dengan SPL lapangan di dapatkan hubungan yang kuat dengan korelasi $R=0,61$. Hubungan tersebut sangat signifikan yang mengindikasikan bahwa data SPL dari MODIS bisa digunakan untuk menganalisis SPL lapangan di Perairan Selatan Jawa - Bali. Berdasarkan analisis korelasi hubungan antara SPL dengan hasil tangkapan ikan tuna didapatkan hubungan terbalik yang rendah, karena kisaran suhu yang cenderung fluktuatif sehingga SPL tidak berpengaruh langsung terhadap hasil tangkapan. Sedangkan hubungan antara klorofil-a dengan hasil tangkapan ikan tuna didapatkan hubungan yang rendah, karena klorofil-a di perairan tidak berpengaruh langsung terhadap hasil tangkapan ikan tuna, melainkan ikan tuna merupakan predator level yang lebih tinggi. 


\section{Ucapan terima kasih}

Penulis mengucapkan terima kasih kepada seluruh pihak yang telah memberikan saran dan bimbingan dalam penelitian ini, khususnya kepada instansi Loka Penelitian Perikanan Tuna (LPPT) Benoa, Bali yang telah memfasilitasi dalam pengambilan data perikanan.

\section{Daftar Pustaka}

Abigail, W., Zainuri, M., Kuswardani, A. T. D., \& Pranowo, W. S. (2015). Sebaran nutrien, intensitas cahaya, klorofil-a dan kualitas air di Selat Badung, Bali pada Monsun Timur. Jurnal depik, 4(2), 87-94.

Adnan. (2010). Analisis suhu permukaan laut dan klorofil-a data inderaja hubungannya dengan hasil tangkapan ikan tongkol (Euthynnus affinis) di perairan Kalimantan Timur. Jurnal "Amanisal" PSP FPIK Unpatti-Ambon, 1(1), 1 - 12.

Amandè, M. J., Chassot, E., Chavance, P., Murua, H., de Molina, A. D., \& Bez, N. (2012). Precision in bycatch estimates: the case of tuna purse-seine fisheries in the Indian Ocean. ICES Journal of Marine Science, 69(8), 1501-1510.

Bender, M. G., Machado, G. R., de Azevedo Silva, P. J., Floeter, S. R., Monteiro-Netto, C., Luiz, O. J., \& Ferreira, C. E. (2014). Local ecological knowledge and scientific data reveal overexploitation by multigear artisanal fisheries in the Southwestern Atlantic. PLoS One, 9(10), e110332.

Habibie, M. N., \& Nuraini, A. F., (2014). Karakteristik dan trend perubahan suhu permukaan laut di indonesia periode 1982-2009. Jurnal meteorologi dan geofisika, 15(1), 37-49.

Hariyanto, T., Baskoro, M. S., Haluan, J., \& Iskandar, H. I. (2008). Pengembangan teknologi penangkapan ikan berbasis komoditas potensial di Teluk Lampung. Jurnal saintek perikanan, 4(1), 16-24.

Hidayah, G., Wulandari, S. Y., \& Zainuri, M. (2016). Studi sebaran klorofil-a secara horizontal di perairan muara Sungai Silugonggo Kecamatan Batangan, Pati. Jurnal buletin oseanografi marina, 5(1), 52 - 59.

IOTC. (2014). Status of the Indian Ocean bigeye tuna (BET: Thunnus Obesus) resource. [online] Tersedia di: http://www.iotc.org/sites/default/files/documents/20 14/12/IOTC-2014-SC17-ES02E_-_Bigeye_tuna.pdf, [diakses: 10 Maret 2016].

Jatmiko, I., Nugraha, B., \& Satria, F. (2015). Capaian perkembangan program pemantau pada perikanan rawai tuna di Indonesia. Journal marine fisheries, 6(1), 23-31.

Kaplan, D. M., Chassot, E., Amandé, J. M., Dueri, S., Demarcq, H., Dagorn, L., \& Fonteneau, A. (2014). Spatial management of Indian Ocean tropical tuna fisheries: potential and perspectives. ICES Journal of Marine Science, 71(7), 1728-1749.

Kasim, F. (2010). Analisis distribusi suhu permukaan menggunakan data citra satelit Aqua-Modis dan perangkat lunak seadas di perairan Teluk Tomini. Jurnal ilmiah agropolitan, 3(1), 270-276.

Limbong, M. (2008). Pengaruh Suhu Permukaan Laut Terlengkap Jumlah Dan Ukuran Hasil Tangkapan Ikan Cakalang Di Perairan Teluk Pelabuhan Ratu Jawa Barat. Skripsi. Bogor, Indonesia: Depertemen Pemanfaatan Sumber Daya Perikanan, Fakultas Perikanan dan Ilmu Kelautan, Institut Pertanian Bogor.

Muqsit, A., Yusfiandayani, R., \& Baskoro, M. S. (2016). analisis komposisi Lambung Madidihan (Thunnus albacares) hasil tangkapan di rumpon perairan kaur menggunakan indeks prepoderans. Jurnal teknologi perikanan dan kelautan, 7(1), 57-68.

Najid, A., Pariwono, J. I., Bengen, D. G., Nurhakim, S., \& Atmadipoera, A. S. (2012). Pola musiman dan antar tahunan salinitas permukaan laut di perairan utara Jawa-Madura. Maspari journal, 4(2), 168-177.

NASA, (2011). About MODIS. [online] Tersedia di: http://modis.gsfc.nasa.gov/about, [diakses: 18 November 2016].

Nuraini, A. F., Santoso, A., \& Redjeki, S. (2014). Morfometri dan komposisi isi lambung ikan tuna sirip kuning (Thunnus albacares) yang didapatkan di pantai Prigi Jawa Timur. Journal of marine research, 2(3), 86-90.

Putra, E,. Lumban-Gaol, J., \& Siregar, V. P. (2012). Hubungan konsentrasi klorofil-a dan suhu permukaan laut dengan hasil tangkapan ikan pelagis di perairan Laut Jawa dari citra satelit Modis. Jurnal teknologi perikanan dan kelautan, 3(1), 1-10

Prasetyo, B. A., Hutabarat, S., \& Hartoko, A. (2014). Sebaran spasial cumi - cumi (Loligo Spp.) dengan variable suhu permukaan laut dan klorofil-a data satelit modis aqua di Selat Karimata hingga Laut Jawa. Diponegoro journal of marquares, 3(1), 51-60.

Santoso, M. I. (2015). Applying Interactive Planning on Public Service Leadership in The Directorate General of Immigration Indonesia. Procedia-Social and Behavioral Sciences, 169, 400-410.

Setiawati, M. D., Sambah, A. B., Miura, F., Tanaka, T., \& As-syakur, A. R. (2015). Characterization of bigeye tuna habitat in the Southern Waters off Java-Bali using remote sensing data. Advances in Space Research, 55(2), 732-746.

Sofarini, D. (2012). Keberadaan dan kelimpahan fitoplankton sebagai salah satu indikator kesuburan lingkungan perairan di Waduk Riam Kanan. Journal enviro scienteae, 8(2), 30-34.

Swastana, I. G. A., As-syakur, A. R., \& Novianto, D. (2016). Karakteristik Ikan Tuna sirip biru selatan (Thunnus maccoyii) Hasil Tangkapan Kapal Rawai 
Tuna yang didaratkan di Pelabuhan Benoa. Journal of Marine and Aquatic Sciences, 2(2), 78-83.

Syah, A. F. (2010). Penginderaan jauh dan aplikasinya di wilayah pesisir dan lautan. Jurnal kelautan, 3(1), 18-28.

Umar, T., Karuwal, J. C., Zainuddin, M., \& Mallawa, A. (2015). Sebaran suhu permukaan laut dan klorofil-a pengaruhnya terhadap hasil tangkapan yellowfin tuna (Thunnus albacares) di perairan Laut Halmahera Bagian Selatan. Jurnal IPTEKS PSP,2(3), 248-260.

Usman, A., Sumadhiharga, O. K., \& Patria, M. P. (2014). Pengelolaan sumber daya ikan kakap merah (Lutjanus spp.) di perairan utara Cirebon, Laut Jawa. Jurnal teknologi perikanan dan kelautan, 5(1), 65-74.

(C) 2017 by the authors; licensee Udayana University, Indonesia. This article is an open access article distributed under the terms and conditions of the Creative Commons Attribution license (http://creativecommons.org/licenses/by/3.0/). 